\title{
Instruments financed by the regional policy
}

\section{INTRODUCTION}

Regional diversification of economic development is not only caused by the entrepreneurship of economic subjects in a given area, but also by the efficiency of territorial socioeconomic systems in a given region.

Therefore the financing of regional development is a very complex process, because there is no main centre for gathering the financial resources and financing investment tasks, but there are series of means created for that purpose.

\section{THE IMPACT OF INTEGRATION FINANCES ON REGIONAL POLICY OF THE EUROPEAN UNION}

The integration finances are strongly interrelated with rules of EU regional financing policy. The aspect of financial integrity is crucial for EU activity as an integration organization. The most important directions of shaping and developing the EU integration finances are ${ }^{1}$ :

- Introduction of facilitation in capital flow

- Assimilation of tax systems

- Unification of budgetary systems

- Unification of financial institutions.

The EU financial integrity is a factor that enables the existence and development of EU regional financing policy. The base of the regional financial policy is the condition to fulfil the specific role of allocation together with both partial stabilization and partial redistribution by the financial subjects; this role enables to transfer financial means from economically stronger countries to less developed member states ${ }^{2}$. The result of EU financial integrity in the field of regional policy is the arrangement of uniform rules on financing the development

\footnotetext{
${ }^{1}$ L. Oręziak, Finanse Unii Europejskiej, Wydawnictwo PWN, Warszawa 2005.

${ }^{2}$ M. Rudnicki, Polityka regionalna Unii Europejskiej: zagadnienia prawno-finansowe, Wydawnictwo Wyższej Szkoły Bankowej, Poznań 2000.
} 
of member states. Mechanisms of the integration financing system put into effect the establishment of structural funds, Cohesion Funds, and other EU means of financing ${ }^{3}$.

The Integration Financing System not only enables the subjects of regional policy to fulfil such tasks as those mentioned above - meaning allocation, stabilization and redistributionbut also allows them to take an effective role in shaping and influencing a specific structure of production and distribution of work and capital within the inner structure of EU ${ }^{4}$.

There is a possibility of governing the processes of structural adjustment due to strict channelling of EU financial means.

The financial integration system allows the financial subjects of regional policy to fulfil a redistributing role in relation to an obligatory secondary division of income and wealth formed in member states. Currently, a vast majority of all EU budgets is destined for regional policy, which marks the importance of redistribution that takes place along with financial subjects of this policy ${ }^{5}$. The Integration Financing System also enables a participation of financial means of regional policy in shaping the stability of economy or contributing to economic stability within the inner structures of EU. This state is achieved by influencing the employment structure in certain fields of economy, also by fulfilling the most important condition needed for economic growth in EU, which is social and economic integrity of all areas of European Union 6 .

Functioning of EU funds - especially structural funds - belongs to crucial problems concerning regional policy of EU. It results from the fact that many regions in countries which belong to the Community characterize with different kinds of modernization and reconstruction needs. Thus, it is very important to develop such mechanisms which will enable absorption of EU funds on region level, then consequently by certain subjects. Most of the reconstruction projects can be financed from the Community budget. European Union, pursuing its socioeconomic integrity policy, has created mechanisms addressed at financing the adjustment processes.

\section{Categories of Instruments Which ReAlize EU's REgional POLICY}

The regional policy of EU includes two categories of instruments, which are responsible for functioning and interaction. These are law and financial instruments. Law instruments are described as certain law and institutional activities, which result in stating law acts, and regulating rules of influencing the regional policy together with development of institutional structures responsible for realization of those law acts. Financial instruments, on the other hand, are described as certain funds from both financial resources of the EU budget and off the budget, which enable the achievement of EU's financial intervention?

\footnotetext{
3 T. Famulska, J. Nowakowski, Finanse i bankowość w integrujqcej się Unii Europejskiej, Centrum Doradztwa i Informacji Difin Sp. z o.o., Warszawa 2006.

${ }^{4}$ B. Bernaś, Finanse Unii Europejskiej, Wydawnictwo Akademii Ekonomicznej we Wrocławiu, Wrocław 2005.

5 A. Marszałek, Integracja ekonomiczna, Polskie Wydawnictwo Ekonomiczne, Warszawa 2004.

${ }^{6}$ E. Dynia, Integracja europejska, Wydawnictwo Prawnicze Lexis Nexis, Warszawa 2006.

7 J. Kaja, K. Piech, Rozwój oraz polityka regionalna i lokalna w Polsce, Oficyna Wydawnicza SGH, Warszawa 2005.
} 
Due to the fact that most of the instruments of regional policy have a very complex character, one can highlight financial-law instruments, such as ${ }^{8}$ :

- Structural funds

- Cohesive funds

- European Investment Bank.

Structural funds are such means of financing which are used for the realization of primary agendas like socioeconomic integrity. Their goal is to support the restructuring and modernization of member state economies. This is the way to influence the growth of socioeconomic integrity of EU. Funds are above all directed to those regions which can't even with average economic growth level of EU without a financial backup 9 .

Structural funds include ${ }^{10}$ :

- European Regional Development Fund, meaning a structural fund of EU whose main task is to decrease the disproportion in the level of growth between the EU's member state regions. From ERDF derives support for production and manufacturing investments along with support given to small and medium entrepreneurs.

- European Social Fund, meaning a structural fund of EU whose main goal is the development of EU's societies. From ESF derives the support for labour-market policy, preventing the social exclusion, adaptation and personnel growth, equalling the opportunities on the labour market.

Curtail financial element supporting the regional policy is voivodship contracts, which are an instrument of implementing country's regional policy on a voivodship scale. They stand for a form of agreement between the government of RP and a self-governing voivodship on the realization of tasks concerning growth and restructuring of the region. Voivodship contract is not a perfect tool for planning regional policy, because it only determines conditions of realization of the regional operating programmes, without taking into account the ongoing operating programmes in given voivodships; this fact doesn't foster coordination of regional growth policy ${ }^{11}$.

\section{FINANCIAL INSTRUMENTS WHICH SUPPORT THE REGIONAL POLICY}

Until the year 2004 Poland had been using pre-accession support, i.e. support from financial resources for countries that wish to become a state member of the European Union. After joining the Community in May of 2004, one could use pre-accession support, whereas in the years from 2004 to 2006 Poland was for the first time using EU resources under the same conditions as other state members. Years from 2007 to 2013 are the years of planning, which results in granting Poland: support for developing certain regions along with the whole

\footnotetext{
${ }^{8}$ Z. Brodecki, Regiony, Wydawnictwo Prawnicze LexisNexis, Warszawa 2005.

9 Z. Brodecki, Finanse, Wydawnictwo Prawnicze LexisNexis, Warszawa 2004.

10 T. Kierzkowski, Fundusze strukturalne, Wydawnictwo C.H.Beck, Warszawa 2009.

${ }^{11}$ L. Patrzałek, Podsektor samorzqdowy $w$ sektorze finansów publicznych $w$ warunkach akcesji Polski do Unii Europejskiej, Wydawnictwo WSB, Poznań 2006.
} 
country, growth of human resources and assimilation of the standard of living in Poland to EU's levels ${ }^{12}$.

During the current period of programming 2007-2013, next to socioeconomic integrity of all EU regions, there is an equally important issue of territorial integrity. Territorial integrity is both complementary and strengthening the socioeconomic integrity, and marks a well-balanced and cohesive development of the entire European Union, in the field of infrastructure, human activity focus and equal opportunities ${ }^{13}$.

The most important goal of the Union funds is to stimulate innovativeness and attractiveness of regions. Very important aspects of regional policy are both education and training ${ }^{14}$.

From the perspective of governing EU's resources, there is a fundamental change in the current period of programming, which results in partial decentralization of implementation of the operational programmes financed from the Structural Funds and Cohesive Funds. Besides the national programmes, 16 regional programmes were formed to substitute The Integrated Regional Operational Programme. TIROP was governed on the country level and its implementation was coordinated on the regional scale ${ }^{15}$. Whereas Regional Operational Programmes are both governed and implemented by voivodships' self-governing authorities. Both TIROP and ROP are programmes supporting development of certain regions potential, including among others: regional infrastructure, meaning health, education, utilization of wastes, sewerage, water supply system, power engineering and information science.

During the years 2004-2006, resources destined for investment around entrepreneurs were given to beneficiaries according to the rules of Sectoral Operational Programme "Growth of Enterprise Competitiveness" ". In the present state of planning, which includes years from 2007 to 2013, Regional Operational Programmes continue to provide support ${ }^{17}$.

Entrepreneurs can also apply for support from the Operational Programme "Innovative Economy", which is most suitable for entrepreneurs realizing innovative investments on a scale which is more than regional.

The Operational Programme "Innovative Economy" not only offers support for innovative entrepreneurs, but also provides support for institutions that are defined as business surrounding, whose role is to stimulate innovativeness and competitiveness of Polish companies. These are local and regional agencies of regional development, entrepreneur incubators, technology transfer centres, and chambers of commerce.

The Sectoral Operational Programme "Growth of Enterprises Competitiveness (SOP GEC)"18, which functioned during years 2004-2006, continues to provide support through the Operational Programme "Human Capital".

\footnotetext{
${ }^{12}$ www.funduszeeuropejskie.gov.pl.

13 A. Filipiak, Fundusze Unii Europejskiej, Agencja Wydawnicza Placet, Warszawa 2009.

14 www.funduszeeuropejskie.gov.pl.

${ }^{15}$ http://www.zporr.gov.pl/.

${ }^{16}$ A. Antoniuk, A. Deoniziak, M. Dziura, T. Sadowski, G. Świderski, Vademecum Beneficjenta. Działanie 2.3 SPO WKP, Warszawa 2007.

${ }^{17}$ Regionalny Program Operacyjny Województwa Zachodnio-pomorskiego na lata 2007-2013, Program Regionalny

- Narodowa Strategia Spójności, Zarząd Województwa Zachodniopomorskiego, 2010.

18 www.konkurencyjnosc.gov.pl.
} 
A significant change in OP HC when compared with SOP GEC is the introduction of two components: central and regional. Within the framework of the central component, the function of intermediary institutions was transferred to proper ministries.

In the case of regional component, the function of intermediary institutions is fulfilled by voivodships' self-governments. Support from the regional component is focused on people who are: unemployed and passive in their profession, endangered by social exclusion, entrepreneurs and their employees or individuals who take part in the educational system ${ }^{19}$.

In the present time of programming, the INTERREG initiative was substituted by a programme called "European Territorial Co-operation", whose goal is realized by tree types of programmes ${ }^{20}$ : trans-border, trans-national, and international ones. This programme is financed by the European Regional Development Fund.

Moreover, in the years 2007-2013 there is an ongoing Operational Programme called Development of Eastern Poland. This instrument constitutes an initiative of the European Committee, whose basic goal is the development of cooperation between the European Union and partnering countries from outside the EU, through assurance of integrated and balanced regional development. Resources from this programme help with the advancement of voivodships ${ }^{21}$ : Warmińsko-Mazurskie, Podlaskie, Lubelskie, Świętokrzyskie, and Podkarpackie. Also, a new instrument of territorial cooperation was established on the Community level, the European Territorial Cooperation. This instrument enables to form law-based arrangements of over-national character, on the territory of the EU, whose task is to support and facilitate territorial cooperation inside the European Union.

\section{Literatura}

Antoniuk A., Deoniziak A., Dziura M., Sadowski T., Świderski G., 2007, Vademecum beneficjenta, Działanie 2.3 SPO WKP, Warszawa

Bernaś B., 2005, Finanse Unii Europejskiej, Wydawnictwo Akademii Ekonomicznej we Wrocławiu, Wrocław

Brodecki Z., 2004, Finanse, Wydawnictwo Prawnicze LexisNexis, Warszawa

Brodecki Z., 2005, Regiony, Wydawnictwo Prawnicze LexisNexis, Warszawa

Dynia E., 2006, Integracja europejska, Wydawnictwo Prawnicze Lexis Nexis, Warszawa

Famulska T., Nowakowski J., 2006, Centrum Doradztwa i Informacji, Difin Sp. z o.o., Warszawa

Filipiak A., 2009, Fundusze Unii Europejskiej, Agencja Wydawnicza Placet, Warszawa

Kaja J., Piech K., 2005, Rozwój oraz polityka regionalna i lokalna w Polsce, Oficyna Wydawnicza SGH, Warszawa

Kierzkowski T., 2009, Fundusze strukturalne oraz Fundusz Spójności, C.H. Beck, Warszawa

Marszałek A., 2004, Integracja ekonomiczna, Polskie Wydawnictwo Ekonomiczne, Warszawa

Oręziak L., 2005, Finanse Unii Europejskiej, Wydawnictwo PWN, Warszawa

Patrzałek L., 2006, Podsektor samorzqdowy w sektorze finansów publicznych $w$ warunkach akcesji Polski do Unii Europejskiej, Wydawnictwo WSB, Poznań

Rudnicki M., 2000, Polityka regionalna Unii Europejskiej: zagadnienia prawno-finansowe, Wydawnictwo Wyższej Szkoły Bankowej, Poznań

\footnotetext{
19 T. Kierzkowski, Fundusze strukturalne oraz Fundusz Spójności, C.H. Beck, Warszawa 2009.

${ }^{20}$ www.ewt.gov.pl/Dokumenty.

${ }^{21}$ www.dotacjeue.org.pl.
} 
Zarząd Województwa Zachodniopomorskiego, 2010, Regionalny Program Operacyjny Województwa Zachodniopomorskiego na lata 2007-2013, Program Regionalny - Narodowa Strategia Spójności

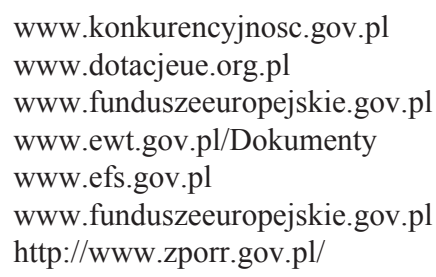

\section{Instruments financed by the regional policy}

The article describes the impact of financial integration on regional policies, instruments and types of financial instruments from the previous and current programming period in order to promote Polish regional policy.

Prof. dr hab. Janusz Soboń

Mgr Roman Szewczyk

Akademia Morska w Szczecinie

e-mail: sj@list.pl 